\title{
Effects of selected nonsteroidal anti-inflammatory drugs on acute-phase protein levels after dehorning in Holstein heifers
}

\author{
HASAN ERDOGAN, IBRAHIM AKIN*, KEREM URAL, PINAR ALKIM ULUTAS** \\ Department of Internal Medicine, *Department of Surgery, **Department of Biochemistry, Faculty of Veterinary Medicine, \\ University of Adnan Menderes, Aydın, Turkey
}

\section{Erdogan H., Akin I., Ural K., Ulutas P. A. \\ Effects of selected nonsteroidal anti-inflammatory drugs on acute-phase protein levels after dehorning in Holstein heifers}

Summary

The purpose of this study was to evaluate the effects of ketoprofen (KTP), flunixin meglumine (FLM), and meloxicam (MLX) administration on acute-phase proteins after dehorning in Holstein heifers. A total of 21 Holstein heifers were enrolled into three groups of equal size $(n=7)$ and administered ketoprofen, flunixin meglumine, or meloxicam, at doses of $2.2 \mathrm{mg} / \mathrm{kg}, 1.1 \mathrm{mg} / \mathrm{kg}$, and $1 \mathrm{mg} / \mathrm{kg}$ body weight, respectively. Serum amyloid $\mathrm{A}$, haptoglobin, and ceruloplasmin levels were determined before the administration of the three drugs $(0 \mathrm{hrs})$ and at $6,12,24,48$, and 96 hours post-administration. The mean values $( \pm$ SD) obtained revealed no significant alteration in APP levels at $0 \mathrm{hrs}$ in any of the three groups. Time-dependent alterations, however, were significant in all groups. Group-time interactions were significant $(P<0.001)$ for ceruloplasmin concentrations, whereas results for serum amyloid $A$ and haptoglobin levels were deemed non-significant. Inter-group interaction revealed no significant findings regarding serum amyloid $A$ and ceruloplasmin levels, but haptoglobin levels showed a significant difference between the KTP and FLM groups at $48 \mathrm{hrs}$. It may therefore be reasonably suggested that KTP, FLM, and MLX could all be administered to effect slight changes in acute phase proteins.

Keywords: dehorning, ketoprofen, flunixine meglumine, meloxicam, acute-phase protein

In the dairy cattle industry, dehorning is a common procedure for decreasing the risk of injury and incidence of carcass wastage and for increasing animal welfare $(4,7)$. Various techniques are involved in the process of dehorning, such as amputation with dehorners, cauterization with hot tools, and application of chemical caustic pastes, such as those containing sodium hydroxide (4). All of these procedures, however, induce behavioral changes consistent with an acute stress response $(20,42)$.

Findings regarding alterations in the levels of fibrinogen, serum amyloid A, $\alpha 1$-acid glycoprotein, and haptoglobin indicate elevated levels of inflammation, trauma, and pain $(11,12,19)$. Ketoprofen, meloxicam, and flunixin meglumine are the most widely used nonsteroidal anti-inflammatory drugs (NSAIDs) in veterinary medicine. These drugs intercept the action of cyclooxygenase (COX) enzymes and diminish prostaglandin levels in the body as a whole (29). As a consequence, pain, inflammation, and fever are reduced (17,
22). Recently, there has been an increasing amount of literature on the effects of acute-phase proteins (APPs) in ruminants undergoing transportation $(15,44)$, infusion of lipopolysaccharide (48), viral spp. infections (e.g. bovine viral diarrhea, respiratory syncytial) (18, 21), and bacterial infections such as Pasteurella haemolytica, P. multocida $(8,24)$. The effects of some NSAIDs on APPs, plasma cortisol behavioral changes and pain management in dehorned calves have been well identified in some previous articles $(14,27,30$, 38). However, the effects of NSAIDs on the dehorninginduced increase in APPs in adult heifers remain unexamined, and limited literature is available on this topic. Furthermore, available data composed of calves with dehorning, whereas no relevant research is indicated within the current literature. This study hypothesizes that ketoprofen (KTP), flunixin meglumine (FLM), and meloxicam (MLX) have potential effects on some APPs (haptoglobin (Hp), serum amyloid A (SAA), and ceruloplasmin $(\mathrm{Cp})$ ) in the dehorning process, which 
is a regular procedure performed on adult ruminants as part of animal welfare management.

To the authors' knowledge, there is no available literature on changes in APP levels after the dehorning of Holstein heifers that received various NSAIDs. The primary aim of this paper, therefore, is to explore the relationship between alterations in positive APPs (Hp, SAA, and $\mathrm{Cp}$ ) in dehorned heifers and KTP, FLM, and MLX administration.

\section{Material and methods}

Animals and dehorning procedure. A total of twentyone $(n=21)$ healthy Holstein heifers from a local dairy farm, aged 9 to 12 months, were divided into three equal groups $(\mathrm{n}=7)$ according to the type of NSAID administered (KTP, FLM, or MLX). This research was performed in agreement with the guidelines for animal experimentation (ADU Ethics Committee no: 64583101/2015/004).

A Barnes dehorner was used for dehorning. The heifers were sedated with xylasine administered intravenously $(0.05 \mathrm{mg} / \mathrm{kg})$. They were then given KTP, FLM, or MLX according to their grouping, 10 minutes before the dehorning procedure, at doses of $2.2 \mathrm{mg} / \mathrm{kg}, 1.1 \mathrm{mg} / \mathrm{kg}$, and $1 \mathrm{mg} / \mathrm{kg}$, respectively.

Blood sampling and laboratory (APPs) analyses. Blood samples were drawn from the 21 heifers prior to the application of sedation and NSAIDs and this was repeated at $6,12,24,48$, and $96 \mathrm{hrs}$ after dehorning. In total, $8 \mathrm{ml}$ of blood was drawn by venipuncture from the jugular vein of the heifers into tubes containing lithium heparin, for APP (including $\mathrm{Hp}$, SAA, and $\mathrm{Cp}$ ) analysis. Plasma samples were obtained by centrifuging the blood for $15 \mathrm{mins}$ at $3000 \mathrm{~g}$. Following this, all plasma specimens were transferred to Eppendorf tubes and kept at $-20^{\circ} \mathrm{C}$ until assays were performed. All plasma specimens were analyzed at the end of the study.

For measurement of haptoglobin and serum amyloid A levels, a commercial ELISA kit (Tridelta Development Ltd., Ireland) was used in accordance with the manufacturer's recommendations. Ceruloplasmin levels were determined by measuring p-phenylenediamine oxidase activity with a spectrophotometer (UV-1601 UV-VIS Spectrophotometer, Shimadzu Corp., Japan).

Statistical analysis. The data on APP levels were described in terms of means, standard deviations, and maxi- mum-minimum values, and then tabulated using descriptive statistics. After the logarithmic transformation process had been applied, the Kolmogorov-Smirnov test confirmed the parameters to be normally distributed. Statistical analyses were then performed with Repeated Measures of ANOVA, and the results were checked with a non-parametric Krusskal Wallis test for time, group, and group-by-time interactions. Significant group-by-time interactions were examined with Bonferroni multiple comparison tests and checked for pairwise interactions with a Krusskal Wallis test for each time period. Results were considered significant at a value of $\mathrm{P}<0.05$. The program SPSS 21.0 (Chicago USA) was used for all tests.

\section{Results and discussion}

In the present study, mean \pm SD data on Hp, SAA, and $\mathrm{Cp}$ levels in Holstein heifers undergoing dehorning were analyzed and compared at different time points throughout the study, from 0 to $96 \mathrm{hrs}$. The data were comparatively evaluated before and after KTP, FLM and MLX administration at different time points. In light of the mean values ( \pm SD) obtained, as shown in Table 1, no significant alterations in levels of APPs were found at $0 \mathrm{hrs}$ in the groups. Time-depended alterations, however, were significant in all groups. Group-time interactions were significant $(\mathrm{P}<0.001)$ regarding $\mathrm{Cp}$ concentrations, whereas the findings regarding SAA and Hp levels were non-significant. Inter-group interaction revealed no significant findings regarding SAA and $\mathrm{Cp}$ concentrations, but there was a significant difference in Hp levels between the KTP and FLM groups at 48 hrs (Tab. 1).

In recent years, the available data have stimulated an increased use of off-label NSAIDs (6). Given this off-label use of medications, such as phenylbutazone, residual problems have started to be seen in the dairy industry. Kopcha et al. (26) performed a study including large-animal veterinarians, which showed that $93 \%$ $(1.325 / 1.424)$ of vets surveyed used NSAIDs more than once a week. In another study, involving dairy veterinarians, it was revealed that NSAIDs are the second most commonly recommended class of medications after antibiotics (40). APPs have been classified as

Tab. 1. Mean \pm SD data of Hp, SAA, and Cp levels in Holstein heifers $(n=7$ heifers/group) undergoing dehorning

\begin{tabular}{|c|c|c|c|c|c|c|c|c|c|}
\hline \multirow{2}{*}{ APPS } & \multirow{2}{*}{ Group } & \multicolumn{6}{|c|}{ Time (hour) } & \multicolumn{2}{|c|}{ Statistical } \\
\hline & & 0. hrs & 6. hrs & 12. hrs & 24. hrs & 48. hrs & 96. hrs & & $P$ value \\
\hline \multirow{3}{*}{$\mathrm{SAA}(\mathrm{mg} / \mathrm{dL})$} & KTP & $35.68 \pm 28.38$ & $51.91 \pm 27.75$ & $77.65 \pm 38.20$ & $125.69 \pm 37.51$ & $159.81 \pm 9.89$ & $112.70 \pm 45.20$ & Group & 0.634 \\
\hline & FLM & $84.07 \pm 108.09$ & $102.13 \pm 97.92$ & $134.06 \pm 96.07$ & $159.44 \pm 51.09$ & $127.48 \pm 43.60$ & $61.41 \pm 45.72$ & Time & 0.000 \\
\hline & MLX & $49.49 \pm 31.00$ & $86.90 \pm 15.37$ & $129.69 \pm 30.18$ & $134.81 \pm 26.18$ & $148.81 \pm 31.83$ & $108.87 \pm 42.58$ & Group*time & 0.082 \\
\hline \multirow{3}{*}{$\mathrm{Hp}(\mathrm{mg} / \mathrm{dL})$} & KTP & $0.25 \pm 0.07$ & $0.41 \pm 0.18$ & $0.31 \pm 0.11$ & $0.38 \pm 0.26$ & $1.19 \pm 0.37$ & $0.88 \pm 0.88$ & Group & 0.031 \\
\hline & FLM & $0.35 \pm 0.35$ & $0.54 \pm 0.36$ & $0.19 \pm 0.09$ & $0.22 \pm 0.12$ & $0.23 \pm 0.08$ & $0.20 \pm 0.13$ & Time & 0.004 \\
\hline & MLX & $0.2195 \pm 0.08$ & $0.52 \pm 0.19$ & $0.34 \pm 0.25$ & $0.30 \pm 0.16$ & $0.91 \pm 0.75$ & $0.61 \pm 0.63$ & Group*time & 0.147 \\
\hline \multirow{3}{*}{$\mathrm{Cp}(\mathrm{mg} / \mathrm{dL})$} & KTP & $13.17 \pm 4.65$ & $12.22 \pm 4.82$ & $11.14 \pm 3.73$ & $13.20 \pm 5.63$ & $11.92 \pm 3.30$ & $11.51 \pm 3.47$ & Group & 0.606 \\
\hline & FLM & $17.78 \pm 10.06$ & $16.15 \pm 9.71$ & $12.63 \pm 11.24$ & $14.66 \pm 10.72$ & $14.15 \pm 10.98$ & $19.67 \pm 13.97$ & Time & 0.015 \\
\hline & MLX & $16.39 \pm 2.22$ & $11.24 \pm 3.95$ & $11.85 \pm 2.90$ & $12.02 \pm 3.45$ & $15.91 \pm 4.97$ & $14.02 \pm 7.36$ & Group*time & 0.073 \\
\hline
\end{tabular}


plasmatic proteins whose circulatory levels alter after inflammation or surgical trauma, such as the dehorning procedure performed in this study $(11,44)$. This might be proposed as the nature of interaction explaining the relationship among dehorned calves and altered APPs.

MLX, grouped within the oxicam class of NSAIDs, has long been used and approved as an adjunct treatment option for diarrhea, mastitis, acute respiratory disorders, and - pertinent to the subject matter of the present study - as an analgesic for relieving pain after dehorning $(5,22,39)$. Given the favorable pharmacological features of this drug, it is likely to provide practical analgesia in cattle, as indicated by the vast majority of researchers, who found it used in this "mixed" way (39). KTP, an NSAID belonging to the propionic acid class, has been approved in some countries for use against inflammatory conditions, fever, and pain (46). Given its short half-life in relation to its quick metabolism and elimination, anti-analgesic application of KTP is likely to require multiple doses (39). Several studies have determined the analgesic properties of $\operatorname{KTP}(9,14,30,32,41)$. FLM is a nicotinic acid byproduct of anthranilic acid and has been approved by the FDA for use in the US dairy industry (36). This drug is usually used for managing fever related to endotoxemia in diseases involving infection, such as mastitis and respiratory disease. In the present study, the authors comparatively evaluated time-dependent and group effects of these three NSAIDs (MLX, KTP, and FLM) on Hp, SAA, and Cp (positive APPs) in heifers undergoing dehorning.

Several methods are used for dehorning cattle in practice, such as amputation with a scoop dehorner (Barnes or Keystone), saw, or wire, and caustic or hot-iron cauterization. Almost all such procedures are known to produce an acute-phase response, regardless of the method used $(20,42)$. Researchers have attempted to evaluate the use of different drugs (analgesic and anaesthetic) in the dehorning process in calves and have pointed out the effects of dehorning on cortisol concentrations, stress levels, pain, and animal welfare (37). The American Association of Bovine Practitioners (AABP) has ranked the dehorning process as more painful than castration when administered to calves over six months of age (13).

A prior research aimed to determine corporeal effects and blood analyte responses after surgical emasculation and/or dehorning, as well as the impact of analgesics and anaesthetics in 90-day-old calves. In that study, treatment $\times$ time interactions $(\mathrm{P}<0.05)$ regarding cortisol and Hp levels were evident. Dehorning caused a more pronounced $(\mathrm{P}<0.05)$ cortisol response than castration did. Hp levels were increased on day 1 following castration $(\mathrm{P}<0.01)(1)$. In the present study, Hp concentration reached its peak levels at $48 \mathrm{hrs}$ in the KTP- and MLX-administered groups, and at $6 \mathrm{hrs}$ in the FLM group, showing statistical significance between the groups $(\mathrm{P}<0.05)$. Time-dependent sig- nificant changes in $\mathrm{Hp}(\mathrm{P}<0.01)$ were evident in all groups at different time points. Regarding SAA concentrations, there was no significant difference found between the groups or in group-by-time interactions. However, time-dependent changes were found to be significant $(\mathrm{P}<0.01)$ for SAA. In all groups, the most striking levels were detected at $24 \mathrm{hrs}$ and $48 \mathrm{hrs}$, compared with the baseline values at $0 \mathrm{hrs}$. Cp values showed similar changes to those in SAA, and striking alterations were also evident at $12 \mathrm{hrs}$.

Increased levels of $\mathrm{Hp}$ (group and group-time), SAA (time), and $\mathrm{Cp}$ (time) detected in this research might be related to probable inflammation, tissue injury, or psychological stress due to dehorning, similar to the effects described for castration $(28,34,42,45,47)$. APPs, including SAA and Hp, are recognized as significant biomarkers for detecting acute inflammatory changes in cattle (23).

Haptoglobin has long been recognized as a potential replacement biomarker for serum cortisol in determining the severity of tissue damage and the effects of analgesic drugs in calves (10). According to the results of the current investigation, significant differences in Hp levels were associated with FLM and MLX administration. There was no statistical difference between KTP and MLX administration in this regard. As is well known, Hp levels can rise due to the inflammatory response. It may be safely speculated that differences in age and surgical procedure might impact $\mathrm{Hp}$ levels (31). On the other hand, preoperative analgesic interventions, such as the administration of NSAIDs, might prevent inflammatory injuries (35). Therefore, the preoperative use of NSAIDs, prior to tissue trauma and inflammatory mediator release, could prove more effective than using these drugs after hyperalgesia has begun (2). In the current study, NSAIDs were used once, prior to dehorning, but the three compounds have different half-lifes and therefore influence APP levels differently (39).

In research aimed at improving animal health and welfare, ceruloplasmin might be useful (44). Previous studies have reported $\mathrm{Cp}$ to be a significant source of data in determining mastitis (3), subclinical mastitis (43), and endometritis (25) in cows. In a prior study on the influence of orchiectomy and dehorning on serum APP levels, sera samples were drawn from seven goats before and after the procedure. The results revealed that the levels of APPs, such as Cp, Hp, $\alpha 1$-acid glycoprotein, and $\alpha 1$-antitrypsin, were continuously elevated to over $403 \%$ when compared to before the procedure (33). In contrast to the current study, there was a decrease in Cp levels in all groups until $12 \mathrm{hrs}$ post-procedure, with irregular changes until the end of the study period, and with no statistical significance between the groups. This might be explained by the administration of all three types of anti-inflammatory drug in this study, which might have modulated $\mathrm{Cp}$ levels, as reported by Filho et al. (16). 
In conclusion, based on different timeline points to those of NSAIDs selected in this study could all be effect slight changes in the levels of acute-phase proteins in dehorned cattle. The results of this study might be useful in drug selection by field veterinarians before a dehorning procedure. Further studies, involving larger cattle populations, are recommended to extend the present findings.

\section{References}

1. Ballou M. A., Sutherland M. A., Brooks T. A., Hulbert L. E., Davis B. L., Cobb $C$. J.: Administration of anesthetic and analgesic prevent the suppression of many leukocyte responses following surgical castration and physical dehorning. Vet. Immunol. Immunopathol. 2013, 151, 285-293

2. Buvanendran A., Kroin J. S., Tuman K. J., Lubenow T. R., Elmofty D., Moric M., Rosenberg A. G.: Effects of perioperative administration of a selective cyclooxygenase 2 inhibitor on pain management and recovery of function after knee replacement: a randomized controlled trial. JAMA 2003, 290, 2411-2418.

3. Chassagne M., Barnouin J., Chacornac J. P.: Biological predictors for early clinical mastitis occurrence in Holstein cows under field conditions in France. Prev. Vet. Med. 1998, 35, 29-38.

4. Coetzee H.: Pain Management, An Issue of Veterinary Clinics: Food Animal Practice, E-Book. Vol. 29. No. 1. Elsevier Health Sciences, 2013.

5. Coetzee J. F., KuKanich B., Mosher R., Allen P. S.: Pharmacokinetics of intravenous and oral meloxicam in ruminant calves. Vet. Ther. 2009, 10, 1-8.

6. Damian P., Craigmill A. L., Riviere J. E.: Extra label use of nonsteroidal antiinflammatory drugs. JAMA 1997, 211, 860-861.

7. Doherty T. J., Kattesh H. G., Adcock R. J., Welborn M. G., Saxton A. M., Morrow J. L., Dailey J. W.: Effects of a concentrated lidocaine solution on the acute phase stress response to dehorning in dairy calves. J. Dairy Sci. 2007, 90, 4232-4239.

8. Dowling A., Hodgson J. C., Schock A., Donachie W., Eckersall P. D., McKendrick I. $J$. : Experimental induction of pneumonic pasteurellosis in calves by intratracheal infection with Pasteurella multocida biotype A:3. Res. Vet. Sci. 2002, 73 , 37-44.

9. Duffield T. F., Heinrich A., Millman S. T., DeHaan A., James S., Lissemore K.: Reduction in pain response by combined use of local lidocaine anesthesia and systemic ketoprofen in dairy calves dehorned by heat cauterization. Can. Vet. J. 2010, 51, 283.

10. Earley B., Crowe M. A.: Effects of ketoprofen alone or in combination with local anesthesia during the castration of bull calves on plasma cortisol, immunological, and inflammatory responses. J. Anim. Sci. 2002, 80, 1044-1052.

11. Eckersall P. D., Bell R.: Acute phase proteins: Biomarkers of infection and inflammation in veterinary medicine. Vet. J. 2010, 185, 23-27.

12. Eckersall P. D., Conner J. G.: Bovine and canine acute phase proteins. Vet. Res Commun. 1988, 12, 169-178.

13. Fajt V. R., Wagner S. A., Norby B.: Analgesic drug administration and attitudes about analgesia in cattle among bovine practitioners in the United States. J. Am. Vet. Med. Assoc. 2011, 238, 755-767.

14. Faulkner P. M., Weary D. M.: Reducing pain after dehorning in dairy calves. J. Dairy Sci. 2000, 83, 2037-2041.

15. Fazio F., Ferrantelli V., Cicero A., Casella S., Piccione G.: Utility of acute phase proteins as biomarkers of transport stress in ewes and beef cattle. IJFS 2015, 4, 4210 .

16. Filho T. A. G., Cooke R. F., Cappellozza B. I., Reis M. M., Marques R. S., Bohnert $D$. W.: Effects of meloxicam administration on physiological and performance responses of transported feeder cattle. J. Anim. Sci. 2014, 92, 4137-4144.

17. Friton G. M., Cajal C., Ramirez-Romero R.: Long-term effects of meloxicam in the treatment of respiratory disease in fattening cattle. Vet. Rec. 2005, 156 809-811.

18. Ganheim C., Hulten C., Carlsson U., Kindahl H., Niskanen R., Waller K. P.: The acute phase response in calves experimentally infected with Bovine Viral Diarrhoea Virus and/or Mannheimia Haemolytica. J. Vet. Med. B. 2003, 50, 183-190.

19. Gilpin D. A., Hsieh C. C., Kuninger D. T., Herndon D. N., Papaconstantinou J. Regulation of the acute phase response genes alpha 1-acid glycoprotein and alpha 1-antitrypsin correlates with sensitivity to thermal injury. Surgery 1996 , 119, 664-673.

20. Grøndahl-Nielsen C., Simonsen H. B., Lund J. D., Hesselholt M.: Behavioural, endocrine and cardiac responses in young calves undergoing dehorning without and with use of sedation and analgesia. Vet. J. 1999, 158, 14-20.

21. Heegaard P. M. H., Godson D. L., Toussaint M. J. M., Tjùrnehùj K., Larsen L. E., Viuff B., Rùnsholt L.: The acute phase response of haptoglobin and serum amyloid A (SAA) in cattle undergoing experimental infection with bovine respiratory syncytial virus. Vet. Immunol. Immunopathol. 2000, 77, 151-159.

22. Heinrich A., Duffield T. F., Lissemore K. D., Squires E. J., Millman S. T.: The impact of meloxicam on postsurgical stress associated with cautery dehorning. J. Dairy Sci. 2009, 92, 540-547.
23. Horadagoda N. U., Knox K. M., Gibbs H. A., Reid S. W., Horadagoda A., Edwards S. E., Eckersall P. D.: Acute phase proteins in cattle: discrimination between acute and chronic inflammation. Vet. Rec. 1999, 144, 437-441.

24. Katoh N., Nakagawa H.: Detection of haptoglobin in the high-density lipoprotein and the very high-density lipoprotein fractions from sera of calves with experimental pneumonia and cows with naturally occurring fatty liver. J. Vet. Med. Sci. 1999, 6, 119-124.

25. Kaya S., Merhan O., Kacar C., Colak A., Bozukluhan K.: Determination of ceruloplasmin, some other acute phase proteins, and biochemical parameters in cows with endometritis. Vet. World. 2016, 9, 1056.

26. Kopcha M., Kaneene J. B., Shea M. E., Ahl A. S.: Use of nonsteroidal antiinfammatory drugs in food animal practice. J. Am. Vet. Med. Assoc. 1992, 201 , 1868-1872.

27. Korkmaz M., Saritaș Z. K., Bülbül A., Demirkan I.: Effect of Pre-Emptive Dexketoprofen Trometamol on Acute Cortisol, Inflammatory Response and Oxidative Stress to Hot-Iron Disbudding in Calves. Kafkas Univ. Vet. Fak. Derg. 2015, 21, 563-568.

28. La Fontaine D.: Dehorning and castration of calves under six months of age Agnote. 2002, 83, 1-6.

29. Mathews K. A.: Nonsteroidal anti-inflamatory analgesics: a review of current practice. J. Vet. Emerg. Crit. Care. 2002, 12, 89-97.

30. McMeekan C. M., Stafford K. J., Mellor D. J., Bruce R. A., Ward R. N., Gregory $N$. G.: Effects of regional analgesia and/or a non-steroidal anti-inflammatory analgesic on the acute cortisol response to dehorning in calves. Res. Vet. Sci. $1998,64,147-150$

31. Mellor D. J., Molony V., Robertson I. S.: Effects of castration on behaviour and plasma cortisol concentrations in young lambs, kids and calves. Res. Vet. Sci. 1991, 51, 149-154.

32. Milligan B. N., Duffield T., Lissemore K.: The utility of ketoprofen for alleviating pain following dehorning in young dairy calves. Can. Vet. J. 2004, 45, 140-143.

33. Nociti R. P., Rocha T. G., Franciosi C., Tavares I. K., da Silva P. C., de Resende $K$. T., Fagliari J. J.: Leucograma e teores de proteínas de fase aguda em caprinos submetidos à orquiectomia e descorna. Ci. Anim. Bras. 2009, 392-397.

34. Pang W. Y., Earley B., Sweeney T., Crowe M. A.: Effect of carprofen administration during banding or burdizzo castration of bulls on plasma cortisol, in vitro interferon-gamma production, acute-phase proteins, feed intake and growth J. Anim. Sci. 2006, 84, 351-359.

35. Portenoy R. K.: Current pharmacotherapy of chronic pain. J. Pain Symptom Manag. 2000, 19, 16-20.

36. Smith G. W., Davis J. L., Tell L. A., Webb A. I., Riviere J. E.: Extralabel use of nonsteroidal anti-inflammatory drugs in cattle. J. Lab. Clin. Med. 2008, 232, 697-701.

37. Stafford K. J., Mellor D. J.: Dehorning and disbudding distress and its alleviation in calves. Vet. J. 2005, 169, 337-349.

38. Stafford K. J., Mellor D. J., Todd S. E., Bruce R. A., Ward R. N.: Effects of loca anaesthesia or local anaesthesia plus a non-steroidal anti-inflammatory drug on the acute cortisol response of calves to five different methods of castration. Res. Vet. Sci. 2002, 73, 61-70.

39. Stock M. L., Coetzee J. F.: Clinical pharmacology of analgesic drugs in cattle. Vet. Clin. North Am. Food Anim. Prac. 2015, 31, 113-138.

40. Sundlof S. F., Kaneene J. B., Miller R. A.: National survey on veterinarianinitiated drug use in lactating dairy cows. JAVMA 1995, 207, 347-352.

41. Sutherland M. A., Mellor D. J., Stafford K. J., Gregory N. G., Bruce R. A., Ward $R$. N.: Cortisol responses to dehorning of calves given a $5 \mathrm{~h}$ local anaesthetic regimen plus phenylbutazone, ketoprofen or adrenocorticotropic hormone prior to dehorning. Res. Vet. Sci. 2002, 73, 115-123.

42. Sylvester S. P., Stafford K. J., Mellor D. J., Bruce R. A., Ward R. N.: Acute cortiso responses of calves to four methods of dehorning by amputation. Aust. Vet. J. 1998, 76, 123-126.

43. Szczubiat M., Dabrowski R., Kankofer M., Bonchniarz M., Komar M.: Concentration of serum amyloid A and ceruloplasmin activity in milk from cows with subclinical mastitis caused by different pathogens. Pol. J. Vet. Sci. 2012, 15, 291-296.

44. Tothova C., Nagy O., Kovac G.: Acute phase proteins and their use in the diagnosis of diseases in ruminants: a review. Vet. Med. 2014, 59, 163-180.

45. Tóthová C. S., Nagy O., Seidel H., Konvićná J., Farkašová Z., Kovác G.: Acute phase proteins and variables of protein metabolism in dairy cows during the pre and postpartal period. Acta. Vet. Brno 2008, 77, 51-57.

46. USP.: Veterinary Pharmaceutical Information Monographs. Anti-inflammatories J. Vet. Pharmacol. Ther. 2014, 27, 1-110.

47. Ward J. L., Rebhun W. C.: Chronic frontal sinusitis in dairy cattle: 12 cases (1978-1989). JAVMA 1992, 201, 326-328.

48. Werling D., Sutter F., Arnold M., Kun G., Tooten P. C. J., Gruys E., Kreuzer M. Characterisation of the acute phase response of heifers to a prolonged low dose infusion of lipopolysaccharide. Res. Vet. Sci. 1996, 61, 252-257.

Corresponding author: Hasan Erdogan, DVM, PhD, Department of Internal Medicine, Faculty of Veterinary Medicine, Adnan Menderes University, Isikli, Aydın, 09017, Turkey; e-mail: hasan.erdogan@adu.edu.tr 